\title{
EVALUATION AND COMPARISON OF RESPIRATORY SYMPTOMS AND LUNG CAPACITIES IN TILE AND CERAMIC FACTORY WORKERS OF YAZD
}

\author{
Gholam Hossein HALVANI ${ }^{1}$, Mohsen ZARE $^{1}$, Abolhasan HALVANII ${ }^{2}$, and Abolfazl BARKHORDARI ${ }^{1}$ \\ Department of Occupational Health', Department of Pulmonary Medicine², Shaheed Sadoughi \\ University of Medical Sciences, Yazd, Iran
}

Received in April 2008

Accepted in July 2008

\begin{abstract}
Tile workers are exposed to dust particles and are susceptible to multiple pulmonary complications. Problems like asthma, chronic obstructive pulmonary symptoms, and silicosis are more common among them. As there are many tile factories in Yazd, we decided to evaluate the respiratory symptoms and lung capacities in these workers and compare them with controls.

This study included 176 tile and ceramic factory workers occupationally exposed to dust and 115 unexposed workers as controls. We recorded the respiratory symptoms using the British Medical Research Council questionnaire and measured lung capacities of the two groups.

All study subjects were male, and the two groups were comparable in age and smoking. The exposed group had frequent respiratory symptoms and a significant relationship between them and duration of employment. In addition, lung capacities in ceramic workers with symptoms were lower than in workers without the symptoms.

Even though the respiratory symptoms were more frequent in the exposed group than in controls, lung capacities of the two groups were similar.
\end{abstract}

KEY WORDS: asthma, ceramic industry, COPD, silicosis

Chronic obstructive pulmonary disease (COPD) is a major cause of chronic morbidity and mortality throughout the world, and further increase in the prevalence and mortality of the disease can be expected in the coming decades (1). Although cigarette smoking is clearly the major risk factor for COPD, there is an increasing recognition that occupational exposure associated with coal mining, hard rock mining, tunnel mining and construction, concrete manufacturing (2), metal foundries, construction industry, glass or ceramics production, and granite or stone industries increase the likelihood of COPD (3). A populationbased investigation has suggested that one in five cases of COPD may be attributed to occupational exposure (4). Workers in tile and ceramic industries are exposed to a variety of dusts which can cause pulmonary diseases. Considering the high prevalence of COPD and preventability of occupational diseases, studies on the effects of specific occupational exposure could have a major public health impact.

Occupational exposure to dust such as crystalline silica, mica, kaolin, quartz, and tridymite is common in tile and ceramic industries. Diseases caused by inhalation of these dusts include silicosis, lung cancer, chronic obstructive pulmonary disease (COPD), and several extra-pulmonary diseases $(5,6)$. Work-related contaminants can produce different lung diseases in different people. These inter-individual differences could be a consequence of numerous factors (7).

Most studies show that pulmonary diseases require exposure to high dust levels for prolonged periods. These studies describe quantitative relationships 
between dust exposure and pulmonary fibrosis, emphysema, airflow obstruction, and reduced lung function as aspects of silicosis $(8,9)$. Oxman et al reviewed the evidence of exposure to occupational dust containing silica and of COPD from 13 reports, including three cohorts of coal miners and one of gold miners without massive pulmonary fibrosis. In all studies, a statistically significant relationship between cumulative respirable dust, loss of lung function, and bronchitis symptoms was found in both smokers and non-smokers (10). Reduced lung function has also been reported with exposure to low levels of concrete dust containing silica (1). A synergistic effect of smoking and silica dust exposure on COPD mortality was shown in South African gold miners (11). Cumulative dust exposure was found to increase the risk of death from COPD in conjunction with smoking (12). At present, numerous tile and granite factories have developed in Iran, and many workers are employed in this industry. We therefore decided to do a research about them. The objectives were to examine the ventilatory effects of exposure to different levels of dust containing crystalline silica, evaluate respiratory symptoms and lung capacities of these workers, and compare them with controls. The study population consisted of exposed workers, while the control population consisted of unexposed workers.

\section{SUBJECTS AND METHODS}

\section{Population}

This study was carried out in 2005-2006. The tile factory in Yazd in central Iran manufactures ceramic and tiles. The prime materials used are silica, kaolin, $\mathrm{Na}_{2} \mathrm{SO}_{4}, \mathrm{NaCO}_{3}$, and $\mathrm{ZnO}_{2}$. The main production processes include the ball mill, the press, the preparation unit, mucilage production, and the furnace. Workers are exposed to dusts and particles from various sections of the plant. Exposed and control subjects were selected to match in age, height, weight, employment years, and smoking status. The 180 exposed male tile workers were randomly selected from a pool of 1350 workers, and for controls we randomly selected 123 unexposed male office workers. We excluded workers with a history of respiratory infections within four weeks from the beginning of the study. Therefore, the group of 180 workers exposed to respirable dust containing silica was reduced to 176 who did not have any recent respiratory infection. In the control group, five workers were excluded due to exposure to respiratory occupational hazards and three whose data were incomplete, and the control group finally counted 115 unexposed workers. Lung function was tested in the winter. All workers were categorised into occupational groups according to department and job title. Informed consent was obtained from all participants.

\section{Questionnaire}

A standardised, self-reporting questionnaire was used and interviews were performed after the lung function tests. The questionnaire was a modified translated version of the British Medical Research Council questionnaire, and questions included demographic information, occupational history, past medical history, use of drugs, respiratory symptoms (cough, sputum, dyspnoea), asthma history, smoking habits, and allergies (13). The subjects were considered to have chronic obstructive pulmonary symptoms (COPS) if they were short of breath when walking with people of their own age on level ground, (dyspnoea grade $\geq 3$ ), cough every day or produced phlegm for three consecutive months over the previous 2 years, or experienced wheezing for more than a week. Criteria for work-related upper respiratory symptoms (WRURS) included more than usual nasal symptoms (prickling or watering nose, or sneezing) at work. Work-related lower respiratory symptoms (WRLRS) were defined as more than usual cough, phlegm production, shortness of breath, or wheezing during at work. Nonsmokers were defined as individuals who had never smoked or smoked less than a total of five packs in their lifetime and current smokers were defined as those who smoked more than one cigarette a day for at least one year.

\section{Lung Function Tests}

Spirometric tests were carried out with a closedsystem, portable FUKUDA ST 300 spirometer with automatic data processing. Measurements and procedures including calibration, data selection, and BTPS correction were in accordance with the standards of the American Thoracic Society (14). A trained assistant performed all lung function measurements. All workers were informed about the investigation and the spirometry test. To exclude a training effect, all workers were made familiar with 
this type of survey one week before the measurements took place. Spirometry was performed between 8 a.m. and 2 p.m. All tests were based on the standards of the American Thoracic Society (16). We recorded forced vital capacity (FVC) and forced expiratory volume in one second $\left(\mathrm{FEV}_{1}\right)$, and used the spirograph $\mathrm{FEV}_{1} /$ FVC ratio and the highest sum of FVC plus $\mathrm{FEV}_{1}$ for analysis.

\section{Workplace Sampling}

Samples of inhalable dust were collected for analysis on glass filters connected to an air sampler pump (model 224-30, SKC) with airflow of $2.5 \mathrm{~L} \mathrm{~min}^{-1}$. We took ten samples for every production unit on randomly selected days of the week, over one month, and calculated the mean. Filters were weighed using the gravimetrical method by weighing filter mass on an electrical balance.

\section{Data Analysis}

All statistical analyses were performed using SPSS 11.5 for Windows (Statistical Products and Service Solutions, Inc., Chicago). Comparisons of crude prevalence rates across the study groups were made using Pearson's chi-square or Fischer's exact test. For testing differences between the means, we used Student's $t$-test or analysis of variance. Statistical significance was defined as the $P$ value of less than 0.05 (two-tailed).

\section{RESULTS}

All exposed and control workers were male. Both groups were of similar age (range: 23-59 years) and standing height, and did not differ significantly in weight, employment years, and smoking status (Table 1). The distribution of workers according to the production unit was as follows: ball mill $5.1 \%$; preparation unit $5.1 \%$; press $33 \%$; mucilage production $26.1 \%$; and furnace $30.7 \%$. The exposed and control group differed significantly in the prevalence of COPS (at least one pulmonary symptom, cough, phlegm, wheezing, or dyspnoea), WRURS, and WRLRS. In the exposed workers, WRLRS were present in $18.8 \%$, WRURS in $17 \%$, and COPS in $21 \%$. In controls, WRLRS were present in $7.8 \%$, WRURS in $5.2 \%$, and COPS in $10.4 \%$. To investigate the relationships between these variables, we used the chi-square test, and the results were statistically significant in the exposed workers (Table1).

The analyses showed that in the exposed group, respiratory symptoms were more frequent in current smokers than in non smokers, but these differences were not statistically significant (Table 2).

Table 3 shows respiratory symptoms in the exposed workers in relation to employment duration. Statistical showed a significant relationship between workers with more than 12 years of employment and respiratory symptoms compared to workers with less than 12 years of employment.

Table 1 Demographics and respiratory symptoms of the exposed tile and ceramic factory workers and controls $(n=291)$

\begin{tabular}{lccc}
\hline $\begin{array}{l}\text { Demographic data and respiratory } \\
\text { symptoms }\end{array}$ & $\begin{array}{c}\text { Exposed workers } \\
(\mathbf{n}=176)\end{array}$ & $\begin{array}{c}\text { Control workers } \\
(\mathbf{n}=115)\end{array}$ & P-value \\
\hline${ }^{1}$ Age / year & $37.7 \pm 7.4$ & $38.4 \pm 8.7$ & n. s. \\
${ }^{1}$ Height / m & $173 \pm 6.7$ & $172.5 \pm 6.6$ & n. s. \\
${ }^{1}$ Weight / kg & $76.2 \pm 11.6$ & $77.2 \pm 12.5$ & n. s. \\
${ }^{1}$ Employment duration / year & $11.3 \pm 4.7$ & $10.4 \pm 4.9$ & n. s. \\
${ }^{2}$ Smokers & $53(30.1 \%)$ & $33(28.7 \%)$ & n. s. \\
${ }^{2}$ Non-smokers & $123(69.9 \%)$ & $82(71.3 \%)$ & n. s. \\
${ }^{2}$ COPS & $37(21 \%)$ & $12(10.4 \%)$ & 0.03 \\
${ }^{2}$ WRURS & $30(17 \%)$ & $6(5.2 \%)$ & 0.003 \\
${ }^{2}$ WRLRS & $33(18.8 \%)$ & $9(7.8 \%)$ & 0.01 \\
\hline
\end{tabular}

${ }^{1}$ Data are presented as mean \pm standard deviation

${ }^{2}$ Data are presented as the absolute number and percent of subjects

n. s. - statistically not significant

COPS - chronic obstructive pulmonary symptoms

WRURS - work-related upper respiratory symptoms

WRLRS - work-related lower respiratory symptoms 
Table 2 Respiratory symptoms in smokers and non smokers in the exposed workers ( $n=176)$

\begin{tabular}{lccc}
\hline \multirow{2}{*}{ Smoking habit } & \multicolumn{3}{c}{ Respiratory symptoms } \\
& WRLRS & WRURS & COPS \\
\hline Smokers $(\mathrm{n}=53)$ & $11(20.7 \%)$ & $10(18.9 \%)$ & $13(24.5 \%)$ \\
Non-smokers $(\mathrm{n}=123)$ & $21(17 \%)$ & $20(16.3 \%)$ & $24(19.5 \%)$ \\
\hline
\end{tabular}

Data are presented as the absolute number and percent of subjects

Note: differences between smokers and non-smokers were not statistically significant

WRLRS - work-related lower respiratory symptoms

WRURS - work-related upper respiratory symptoms

COPS - chronic obstructive pulmonary symptoms

Table 3 Respiratory symptoms in the exposed workers with different employment duration

\begin{tabular}{lccc}
\hline & \multicolumn{3}{c}{ Respiratory symptoms } \\
Employment duration / year & WRLRS $(\mathrm{n}=33)$ & WRURS $(\mathrm{n}=30)$ & COPS $(\mathbf{n}=37)$ \\
\hline 1 to $4(\mathrm{n}=27)$ & $2(6 \%)$ & $3(10 \%)$ & $2(5.4 \%)$ \\
4 to $8(\mathrm{n}=24)$ & $3(9 \%)$ & $1(3.5 \%)$ & $2(5.4 \%)$ \\
8 to $12(\mathrm{n}=10)$ & $2(6 \%)$ & $1(3.5 \%)$ & $3(8.2 \%)$ \\
$>12(\mathrm{n}=115)$ & $26(79 \%)^{*}$ & $25(83 \%)^{*}$ & $30(81 \%)^{*}$ \\
\hline
\end{tabular}

Data are presented as the absolute number and percent of subjects

$* P<0.05$ compared to subjects who had worked in the ceramic factory for less than 12 years

COPS - chronic obstructive pulmonary symptoms

WRURS - work-related upper respiratory symptoms

WRLRS - work-related lower respiratory symptoms

Table 4 shows the distribution of lung function, expressed as percentage of the predicted normal lung function, in the exposed workers and controls. Mean $\mathrm{FVC}, \mathrm{FEV}_{1}$, and $\mathrm{FEV}_{1} / \mathrm{FVC}$ were lower in the exposed group than in controls, but the difference was not statistically significant.

Furthermore, there were no significant differences in the lung function and respiratory symptoms between the exposed workers from different production units. Workers with respiratory symptoms had lower FVC and $\mathrm{FEV}_{1}$ than workers without respiratory symptoms, the $t$-test showed a significant relationship between these parameters $(P=0.02)$. In the control group, lung function did not have a significant association with respiratory symptoms. Table 5 shows mean concentrations of total particles in the ambient air at different production units.

\section{DISCUSSION}

This study suggests that exposure to dust in ceramic manufacture is associated with a significant prevalence of respiratory symptoms. We observed a higher prevalence of WRLRS, WRURS, COPS in the exposed group than in control population. Recent studies have brought strong evidence that occupational exposure to dust can alone cause COPD. Myers and Cornell (15) reported a clear effect of exposure to extremely high dust levels on FVC and $\mathrm{FEV}_{1}$ in 268 South African brickworkers. The results of their study also demonstrated a clear association between acute and chronic respiratory symptoms, self-reported dust exposure, and evidence of airflow limitation, independent of the effect of smoking. Sakar et al. (16) performed a study to estimate the incidence of silicosis and its relation with workrelated factors among workers exposed to silica in the ceramic industry. Cough and sputum rates were higher in the silicosis group. It was concluded that the ceramic industry was associated with a higher risk of silicosis and this risk increased with exposure duration and age. Dust is the major cause of damage to the respiratory epithelium and chronic inflammation of the airways, resulting in respiratory symptoms such as cough, sputum, and shortness of breath 
Table 4 Mean lung function in the exposed and control workers

\begin{tabular}{lccccc}
\hline Lung function & \multicolumn{2}{c}{$\begin{array}{c}\text { Exposed workers } \\
(\mathbf{n}=176)\end{array}$} & \multicolumn{2}{c}{$\begin{array}{c}\text { Control workers } \\
(\mathbf{n}=\mathbf{1 1 5})\end{array}$} & P-value \\
& $\%$ & SD & $\%$ & SD & \\
\hline FVC & 81.4 & 12.3 & 82 & 13 & n. s. \\
FEV1 & 83.5 & 12.4 & 84.7 & 15.1 & n. s. \\
FEV1/FVC & 102.8 & 11 & 103.1 & 11.2 & n. s. \\
\hline
\end{tabular}

Table 5 Total dust concentrations measured in the air sampled in different production units of the ceramic factory

\begin{tabular}{lc}
\hline Production units & $\begin{array}{c}\text { Total dust concentration } / \mathrm{mg} \mathrm{m}^{-3} \\
\text { Mean } \pm \mathrm{SD}\end{array}$ \\
\hline Mucilage production $(\mathrm{n}=10)$ & $2.1 \pm 0.168$ \\
Furnace $(\mathrm{n}=10)$ & $4.2 \pm 0.345$ \\
Ball mill $(\mathrm{n}=10)$ & $6.7 \pm 0.620$ \\
Preparation unit $(\mathrm{n}=10)$ & $7.5 \pm 0.672$ \\
Press $(\mathrm{n}=10)$ & $13.2 \pm 1.34$ \\
\hline
\end{tabular}

$n=$ number of air samples

(17). The above mentioned studies and the results of our study point out that airway obstruction and (work-related) respiratory symptoms are present in workers exposed to relatively high levels of respirable dust containing silica. In a study by Bahrami et al., workers in ceramic factories reported more respiratory symptoms than controls, but the differences were not statically significant (18). Respiratory symptoms in workers exposed to dust were also more frequent than in controls, but the difference was not significant (18), which may have been affected by the number of samples taken or by the use of personal protective equipment. The classification of smoking was based on self-reported information from a standardised questionnaire. Current smokers had more symptoms than nonsmokers. Smoking is the leading cause of COPD, but occupational factors can also result in COPD (19). Concomitant smoking and exposure to occupational contaminants raises this incidence (7, 20).

Years of work also showed to be an important independent determinant for respiratory symptoms and lung function in these workers. In our exposed group, individuals with more than 12 years of work had more respiratory symptoms. A study of workers in a porcelain factory by Plovets'ka revealed that the incidence of respiratory system disorders, mostly acute respiratory viral infections (ARVI), was the most common in workers with up to 10 years of work, whereas pneumonia was the most common in those who had worked for over 10 years (21). The longer the employment, the higher is the frequency respiratory disease, as workers get exposed to more and more work-related contaminants (7).

The observed relationship between exposure to dust and lung function may have been affected by selection bias. However, for our analyses we have used a control population with similar demographic characteristics age, height, weight, years of employment. In the exposed workers, lung function tests were near normal, but lower than in controls, although there was no significant difference from the control group. Findings of different studies vary between different industries. In an investigation carried out by Sakar et al., $F E V_{1}$ and $F V C$ were lower in the "silica" group, but this was not statistically significant (16). A longitudinal study in 711 granite workers showed no statistically significant association between lower FVC or $\mathrm{FEV}_{1}$ and employment duration at mean respirable dust levels of $0.6 \mathrm{mg} \mathrm{m}^{-3}$ (with a $10 \%$ silica content) (22). In contrast, a South African study showed a higher incidence of chronic bronchitis associated with impaired lung function in gold miners than in non-miners, independent of smoking. These findings were strongly related to exposure to silica-containing dust, and not to a specific silicotic effect in the lungs. 
Studies in granite workers have shown a drop in lung function at average silica levels ranging from below $0.1 \mathrm{mg} \mathrm{m}^{-3}$ to $0.16 \mathrm{mg} \mathrm{m}^{-3}(23,24)$. An Iranian study by Bahrami et al. in four occupation groups showed that the lung function of ceramic workers who worked for less than 20 years was similar to that of controls, but dropped significantly in ceramic workers with more than 20 years of employment (18). As the length of exposure in our study was less than 20 years, it is possible that it will take more time for adverse effects on lung function to appear. In other words, if we repeat this study in ten years our exposed group may show a significant drop in lung function grouping respect to controls. Lung function begins to drop at the age of 25 to 30 years, and tobacco smoke accompanied by exposure workplace reduces it further (25).

In our study, workers with respiratory symptoms had a lower lung function than workers without respiratory complaints. Individuals with impaired lung function do not always have more respiratory symptoms, but a correlation between these two has already been reported (26). The presence of chemical vapours, fumes, odours and other mineral dusts, should also be taken into account, as they may contribute to the respiratory effects. Although workers are exposed to a mixture of occupational contaminants, including diesel exhausts, previous studies have shown that the respiratory effects may largely be contributed to the inhalation of silicaceous dust (5). In our study, mean forced ventilatory volumes were relatively low in both groups, and belonged to the lower end of normal, according to the standards proposed by the European Respiratory Society (27).

\section{CONCLUSION}

In conclusion, although respiratory symptoms in ceramic workers in various production units of the factory were more frequent than in controls, lung function tests do not show a clear reduction. Since the harmful effects of occupational dust have been found by various studies, especially at longer exposure times, lung function $\left(\mathrm{FEV}_{1}, \mathrm{FVC}, \mathrm{FEV}_{1} / \mathrm{FVC}\right)$ of workers exposed to silica dust is expected to deteriorate with the duration of employment.

\section{Acknowledgements}

The authors wish to thank the management of the tile and ceramic factory in Yazd and all the supervisors and workers for their cooperation.

\section{REFERENCES}

1. Anto JM, Vermeire P, Vestbo J, Sunyer J. Epidemiology of chronic obstructive pulmonary disease. Eur Respir J 2001;17:982-94.

2. Attfield MD, Moulton LH. Exposure-response relationships for coal mine dust and obstructive lung disease following enactment of the Federal Coal Mine Health and Safety Act of 1969. Am J Ind Med 1992;21:715-34.

3. American Thoracic Society (ATS). Adverse effects of crystalline silica exposure. Am J Crit Care Med 1997; 155:761-5.

4. Trupin L, Earnest G, San Pedro M, Balmes JR, Eisner MD, Yelin E, Katz PP, Blanc PD. The occupational burden of chronic obstructive pulmonary disease. Eur Respir J 2003;22:462-9.

5. Weill H, Jones RN, Parkes WR. Silicosis and related diseases. In: Parkes WR editor. Occupational lung disorders. 3rd ed. Oxford: Butterworth-Heinemann; 1994. p. 285-339.

6. International Agency for Research on Cancer (IARC). Monographs on the evaluation of carcinogenic risk of chemicals to humans - silica, silicates, coal dust and organic fibers. Vol. 68. Lyon: IARC; 1997.

7. Beckett WS. Occupational respiratory diseases. NEngl J Med 2000;342:406-13.

8. Cowie RL, Mabena SK. Silicosis, chronic airflow limitation, and chronic bronchitis in South African gold miners. Am Rev Respir Dis 1991;143:80-4.

9. Steenland K, Brown D. Silicosis among gold miners: exposure-response analyses and risk assessment. Am J Publ Health 1995;85:1372-7.

10. Oxman AD, Muir DC, Shannon HS, Stock SR, Hnizdo E, Lange HJ. Occupational dust exposure and chronic obstructive pulmonary disease. A systematic overview of the evidence. Am Rev Respir Dis 1993;148:38-48.

11. Hnizdo E. Combined effect of silica dust and tobacco smoking on mortality from chronic obstructive lung disease in gold miners. Br J Ind Med 1990;47:65664.

12. Reid PJ, Sluis-Cremer GK. Mortality of white South African gold miners. Occup Environ Med 1996;53:1116.

13. British Medical Research Council (BMRC). Standardized questionnaires on respiratory symptoms. Br Med J 1960;2:1665.

14. Buist AS, Celli B, Dahl R, Figueroa-Casas JC, Jenkin C, Montemayor T, Rauscher H, Siafakas NM, Vestbo J. Panel discussion on ATS and ERS guidelines: is there a need for national guidelines? Eur Respir Rev 1996;39:250-2.

15. Myers JE, Cornell JE. Respiratory health of brickworkers in Cape Town, South Africa. Symptoms, signs and pulmonary function abnormalities. Scand J Work Environ Health 1989;15:188-94. 
16. Sakar A, Kaya E, Celik P, Gencer N, Temel O, Yaman $N$, Sepit L, Yildirim CA, Dagyildizi L, Coskun E, Dinç G, Yorgancioglu A, Cimrin AH. Evaluation of silicosis in ceramic workers.. Tuberk Toraks 2005;53:148-55.

17. Blanc PD, Toron K. Occupation in chronic obstructive pulmonary disease and chronic bronchitis: an update [State of the Art Series. Occupational lung disease in high-and low-income countries, edited by M. ChanYeung, number 2 in the series]. Int J Tuberculosis Lung Dis 2007;11(3):251-7.

18. Bahrami AR, Mahjub H. Comparative study of lung function in Iranian factory workers exposed to silica dust. East Mediterr Health J 2003;9:390-8.

19. Hendrick DJ. Occupational lung disease - 9: Occupation and chronic obstructive pulmonary disease (COPD). Thorax 1996;51:947-55.

20. Kaufmann F, Drouet D, Lellouch J, Brille D. Twelve years spirometric changes among Paris area workers. Int J Epidemiol 1979;8:201-12.

21. Plovets'ka IA. Epidemiologic characteristics of bronchopulmonary diseases in workers in the porcelain industry. Lik Sprava 2000;6:109-11.

22. Graham WG. Longitudinal pulmonary function losses in Vermont granite workers. A reevaluation. Chest 1994;106:125-30.
23. Theriault GP, Peters JM, Fine LJ. Pulmonary function in granite shed workers of Vermont. Arch Environ Health 1974;28:18-22.

24. Malmberg P, Hedenstrom H, Sundblad BM. Changes in lung function of granite crushers exposed to moderately high silica concentrations: a 12 year follow up. Br J Ind Med 1993;50:726-31.

25. Neukirch F, Cooreman J, Korobaeff M, Pariente R. Silica exposure and chronic airflow limitation in pottery workers. Arch Environ Health 1994;49:459-64.

26. Shingo S, Zhang J, Reiss TF. Correlation of airway obstruction and patient-reported endpoints in clinical studies. Eur Respir J 2001;17:220-4.

27. Wanger J, Clausen JL, Coates A, Pedersen OF, Brusasco V, Burgos F, Casaburi R, Crapo R, Enright P, van der Grinten CPM, Gustafsson P, Hankinson J, Jensen R, Johnson D, MacIntyre N, McKay R, Miller MR, Navajas D, Pellegrino R, Viegi G. Standardisation of the measurement of lung volumes. Eur Respir $\mathrm{J}$ 2005;26:511-22. 


\section{Sažetak}

\section{OCJENA I USPOREDBA RESPIRATORNIH SIMPTOMA I KAPACITETA PLUĆA U RADNIKA TVORNICE KERAMIČKIH PLOČICA IZ YAZDA U IRANU}

Radnici u proizvodnji keramičkih pločica izloženi su česticama prašine te su skloni višestrukim plućnim komplikacijama. U njih je veća učestalost tegoba poput astme i simptoma kronične opstruktivne bolesti pluća te silikoze. Budući da u Yazdu ima mnogo tvornica keramike, odlučili smo upravo u tome gradu ocijeniti respiratorne simptome i izmjeriti kapacitet pluća njihovih radnika i usporediti ih s kontrolnom skupinom. Ispitivanje je stoga obuhvatilo 176 radnika u proizvodnji keramičkih pločica izloženih prašini te 115 neizloženih radnika koji su činili kontrolnu skupinu. Respiratorni su se simptomi ispitali rabeći upitnik Britanskoga savjeta za medicinska istraživanja (British Medical Research Council), a u obje je skupine izmjeren kapacitet pluća.

Svi su ispitanici bili muškarci, a skupine su se podudarale po dobi i pušenju. Respiratorni simptomi bili su česti u izloženoj skupini te je u njoj uočena značajna povezanost između respiratornih simptoma i radnoga staža u tvornici. Usto su izloženi radnici s respiratornim simptomima iskazali slabije kapacitete pluća od radnika bez simptoma. Ovi su respiratorni simptomi bili češći u izloženoj skupini negoli u kontrolnoj, ali se njihovi kapaciteti pluća nisu bitno razlikovali.

KLJUČNE RIJEČI: astma, keramička industrija, KOPB, silikoza

\section{CORRESPONDING AUTHOR:}

Halvani Gholam Hossein

Department of Occupational Health, Shaheed

Sadoughi University of Medical Sciences, YAZD-IRAN

E-mail: Halvanig@yahoo.com 